\title{
Commentary: Mitral repair-Where it all comes together?
}

\author{
Louis H. Stein, MD, PhD, and Lewis W. Britton, $\mathrm{MD}$
}

\author{
From the Division of Cardiothoracic Surgery, Department of Surgery, Albany Medical College, Albany, NY. \\ Disclosures: Authors have nothing to disclose with regard to commercial support. \\ Received for publication Aug 4, 2019; accepted for publication Aug 5, 2019; available ahead of print Oct 6, 2019. \\ Address for reprints: Louis H. Stein, MD, PhD, Division of Cardiothoracic Surgery, Albany Medical Center Sur- \\ geons Pavilion, 3rd Floor, 50 New Scotland Ave, Albany, NY 12208 (E-mail: steinl1@amc.edu). \\ J Thorac Cardiovasc Surg 2020;159:e187 \\ $0022-5223 / \$ 36.00$ \\ Copyright () 2019 by The American Association for Thoracic Surgery \\ https://doi.org/10.1016/j.jtcvs.2019.08.047
}

In this issue of the Journal, Grinberg and coworkers ${ }^{1}$ present the prototype of a device under their development that is intended to map mitral leaflet coaptation. This device is composed of a thin array of 28 piezoelectric strain gauges arranged in 3 rows. The array is inserted into the valve orifice along the line of mitral leaflet coaptation. The deformation of the sensor by each leaflet, termed the coaptation force, is measured. This is a high-tech evaluation of the zone of leaflet apposition, one of the pillars of mitral valve repair. ${ }^{2,3}$ This device can quantitate leaflet apposition in the beating heart before the separation from bypass, evaluating under different loading conditions and providing a valuable adjunct to echocardiography.

Each sensor records the magnitude to which it is deformed by the opposing leaflet segment as a change in electrical potential energy (in volts). This recording provides a map of apposition showing the heterogeneity of apposition along the width and depth of leaflet coaptation. The next phases of study will require accrual and interpretation of data and clinical application. Quantitating coaptation has the potential to give new insight into the pathophysiology of mitral regurgitation and thus its correction.

Leaflet coaptation it is the coalescence of transvalvular pressure, intrinsic properties of the leaflet tissue, chordal integrity, left ventricular geometry, and annular size and structure, with each factor a variable in solving the riddle of mitral regurgitation. ${ }^{4,5}$ Correspondingly, the surgeon has a variety of repair techniques at his or her disposal, including leaflet resection, annuloplasty, neochordae, and chordal transposition. A dynamic topographic map of leaflet coaptation could guide the surgeon in determining the adequacy of repair and potentially aid in choosing the

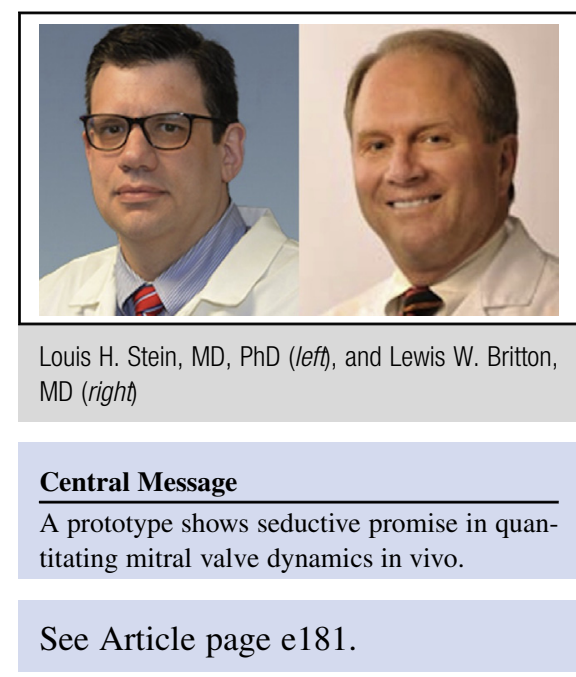

optimal repair technique. As with any measurement, effective use will require accurate interpretation.

Grinberg and coworkers ${ }^{1}$ present a nascent technology that has the potential to help ensure a good and durable mitral repair. It is a long way from these preliminary ex vivo data to clinical utility, but it is an intriguing and promising concept. Treatment of valvular heart disease is moving toward progressively less invasive approaches. Devices such as this can aid as a functional visualization of leaflet coaptation. We are perhaps most excited by the device's potential as an investigational tool.

\section{References}

1. Grinberg D, Bruhat A, Cottinet PJ, Le MQ, Adams DH, Costa A. Mitral valve repair based on physical characterization of coaptation forces. J Thorac Cardiovasc Surg. 2020;159:e181-3.

2. Anyanwu AC, Adams DH. The intraoperative "ink test": a novel assessment tool in mitral valve repair. J Thorac Cardiovasc Surg. 2007;133:1635-6.

3. Anderson RH, Kanani M. Mitral valve repair: critical analysis of the anatomy discussed. Multimed Man Cardiothorac Surg. 2007;2007:mmcts.2006.002147.

4. Gogoladze G, Dellis SL, Donnino R, Ribakove G, Greenhouse DG, Galloway A, et al. Analysis of the mitral coaptation zone in normal and functional regurgitant valves. Ann Thorac Surg. 2010;89:1158-61.

5. Vergnat M, Jackson BM, Cheung AT, Weiss SJ, Ratcliffe SJ, Gillespie MJ, et al Saddle-shape annuloplasty increases mitral leaflet coaptation after repair for flail posterior leaflet. Ann Thorac Surg. 2011;92:797-803. 